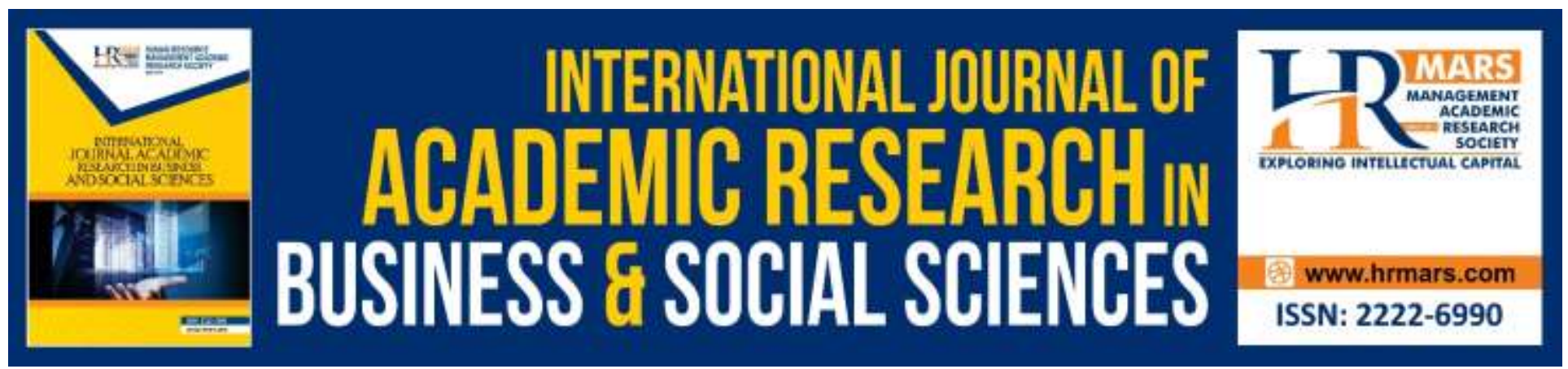

\title{
Modern Day Myths in Neil Gaiman's American Gods
}

\author{
Syed Mikhail Bin Mohamed Roslan, Rohimmi Bin Noor, Hardev Kaur
}

To Link this Article: http://dx.doi.org/10.6007/IJARBSS/v10-i3/7056

DOI:10.6007/IJARBSS/v10-i3/7056

Received: 06 February 2020, Revised: 24 February 2020, Accepted: 14 March 2020

Published Online: 30 March 2020

In-Text Citation: (Roslan et al., 2020)

To Cite this Article: Roslan, S. M. B. M., Noor, R. Bin, \& Kaur, H. (2020). Modern Day Myths in Neil Gaiman's American Gods. International Journal of Academic Research in Business and Social Sciences, 10(3), 370-385.

Copyright: (C) 2020 The Author(s)

Published by Human Resource Management Academic Research Society (www.hrmars.com)

This article is published under the Creative Commons Attribution (CC BY 4.0) license. Anyone may reproduce, distribute, translate and create derivative works of this article (for both commercial and non-commercial purposes), subject to full attribution to the original publication and authors. The full terms of this license may be seen

at: http://creativecommons.org/licences/by/4.0/legalcode

\section{Vol. 10, No. 3, 2020, Pg. 370 - 385}

Full Terms \& Conditions of access and use can be found at http://hrmars.com/index.php/pages/detail/publication-ethics 


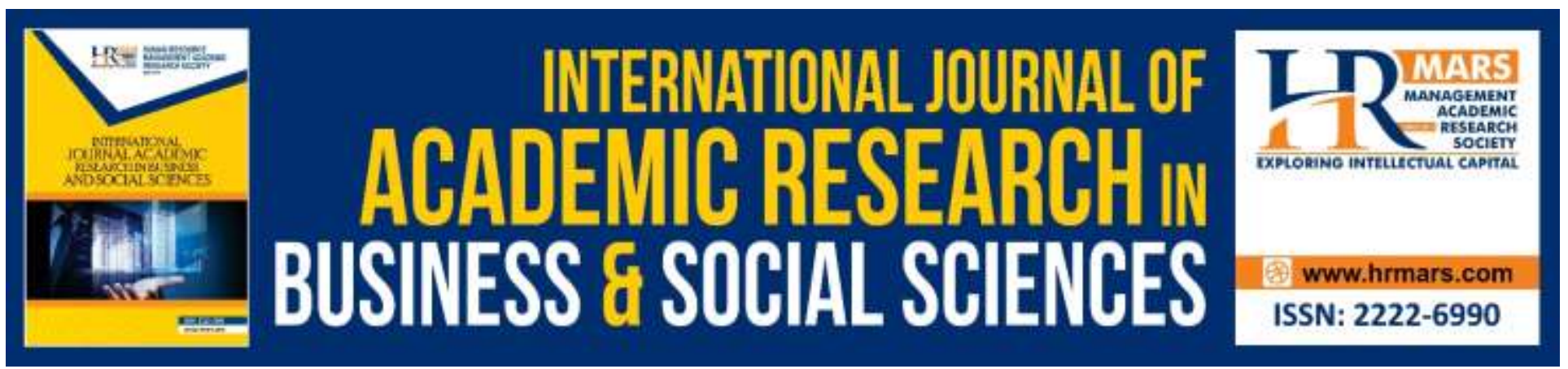

\title{
Modern Day Myths in Neil Gaiman's American Gods
}

\author{
Syed Mikhail bin Mohamed Roslan, Rohimmi bin Noor, Hardev Kaur \\ University Putra Malaysia, Serdang, Malaysia \\ Email: syed.mik7786@yahoo.com
}

\begin{abstract}
This thesis will focus on the function of multi-mythology in contemporary literature especially the fantasy genre. In particular, this thesis analyses American Gods by Neil Gaiman by drawing upon Claude Lévi-Strauss' and Vladmir Propp's structuralist ideas and to see how the original myths were substituted, modulated or transfigured to be presented as metamyth or myth transformed. In particular, I will argue that American Gods is a demonstration of Joseph Campbell's theory of the monomyth from the The Hero with a Thousand Faces. The findings of this study may encourage future researchers into analysing other texts and finding similar themes to fill in the gaps of existing knowledge in mythology.
\end{abstract}

Keywords: American Gods, The Hero with a Thousand Faces, Monomyth, The Hero's Journey

\section{Introduction}

American Gods (AG) is a mythological epic set in modern-day America. Helfrich (2005) describes it as "a dark and kaleidoscopic journey deep into myth and across an America that is at once eerily familiar and utterly alien" (http://arts.uchicago.edu/gaiman.html). American Gods is about a surrealistic version of modern America that is secretly inhabited by the weakened and old spirits of every god of every religion that had ever been brought to the country's shores. American Gods is written from the perspective of a British expatriate living in America. It is a representation of modern-day America and its identity. He accomplishes this by using "...myths to define what makes America" (Rimmels, 2001). In order to construct a modernized mythic portrayal in his novel, Gaiman reshapes and reinvents the vast mythology by combining it with legends, folktales, and numerous intertextuality references.

Gaiman has adopted Campbell's The Hero's Journey or the monomyth as found in his book, 'The Hero with a Thousand Faces" to show us that a protagonist's (in this case Shadow's) journey is the same irrespective of different cultural backgrounds and beliefs. Campbell's The Hero's Journey comprises three rites of the passage: separation, initiation and return and consists of 17 steps. Campbell used the idea of Jung's theory of archetypes to map out the common underlying structure behind all religion and myth. In doing so, Campbell wanted to show that people are essentially the same, no matter where they come from. The aspect this paper will be scrutinizing is to see how American Gods 
can serve the function of Campbell's myth of the 'Monomyth'. American Gods has the indications of being an actual modern myth that resembles the myths of ancient times.

This study utilises the close reading method, which makes it a necessity that the selected text, in this case American Gods, is interpreted and researched from the story's plot and narration. It is a critical analysis of a text whose focal point is on its noteworthy details or patterns in order to form a comprehensive examination of the text's form, craft, and meanings. Ivor Armstrong Richards and his student William Empson were the pioneers of the close reading technique, in regards to the contemporary English literary practice. In the mid-twentieth century, close reading was developed by the New Critics, pioneered by John Crowe Ransom. According to his book, The New Criticism (1941), he believed that the text is complete by itself, thus adequate for interpretation, and a reader should exclusively look at the text, and nothing else, in order to scrutinize it and obtain the true nature and meaning of the text. Using this method, a New Critic is able to review the "formal elements" of the text, such as characterization, setting of time and place, point of view, plot, images, metaphors, ironies and symbols to interpret the text and ultimately discover its theme.

Close reading is a method of deep analysis of the inner workings of a literary text; it is both a reading process and something that is inclusive in a literary analysis paper, albeit in a more refined form. The main objective of this method is to obtain how a piece of literature functions as a self-contained, selfreferential aesthetic object (Bloom, 2016, p.34).

\section{Problem Statement}

Scholars who studied comparative mythology and religion have noticed a trait shared by myths from various cultures across the world and even from ones that had exist once before. A plethora of these myths had a similar elementary commonality in theme, structure and as well as symbolism. The question then arises to how is it that these commonalities are consistently found in an array of nonidentical cultures throughout the world. Joseph Campbell proposed that these parallelisms occur due to a legion of symbols and mythological themes that originate from mankind's collective unconscious, a term made famous by Carl Jung, whom Campbell has mentioned and attributed his studies to, many times in his book The Hero with a Thousand Faces.

The reason why it is important to study the Hero's Journey, is because it is a known and proven fact that mythologies of yesteryears did incorporate this type of storytelling structure in their myths. However, does it still occur in a more advance and modern time such as the twenty-first century, or has society moved past that archaic way of conveying these anecdotes. This paper intends to discover if the Hero's Journey can still be found in contemporary works of literature, or to be more precise, the novel American Gods by Neil Gaiman. This is relevant as this paper aims to unravel if society has changed or rather evolve their storytelling structures, or have they kept the same primeval method that their ancestors had used a millennia ago.

There are a multitude of other scholarly works that implement Campbell's the Hero's Journey, however there are some parts to their works that can be improved on. For example, Andrew Barton referred to Campbell in his study entitled: "The Knight's Progress and Virtual Realities: The Medieval Adventure from Beowulf to Ready Player One." His work merely reiterates the original works of literature, as it aimed to ratify that the books The Lord of the Rings and Ready Player One contain medieval-like characteristics in their storytelling structure. His work did prove to be successful, but it neither properly categorised the events of the stories into Campbell's seventeen stages, nor the three 
phases of the Hero's Journey. Therefore it is the aim of this paper to classify the events of the novel into the seventeen stages in orderto confirm that it does follow the Hero's Journey template of storytelling. It is the intention of the writer to evaluate why certain events fit certain stages, and by doing so on is able to comprehend how works of literature are able to fit into the Hero's Journey narrative.

Bc. Lenka Koudelkova of the Masaryk University had also conducted a similar type of research entitled: "Neil Gaiman: Myths in Postmodern Literature", which is a compilation of American Gods, The Sandman, and the retelling of two classic fairy tales, Snow White and Sleeping Beauty. The researcher is able to prove that American Gods does have the three phases of the Hero's Journey, but did not go into detail in terms of each of the seventeen stages, which are the foundation of each phase. In brief, the same can be said of the other two parts of her study. This lack of detailed explanation leaves this research wide open to critique from a Campbellian standpoint, as the main foundation of Campbell's the Hero's Journey are the stages themselves, and the phases are merely a brief overview or summary of the stages.

In every historical era, there are challenges, hardships or even crises that mankind has to endure and ultimately overcome. It is these harsh times that shape and determine the value of each and every culture. In response, these ideals mould their literary works and also their various heroes. Famous examples such as Hercules, Beowulf and Roland are a testament to that fact as they are the personification of their society's ideals and desires. Cousineau (2003) states that:

"The journey of the hero is about the courage to seek the depths; the image of creative rebirth; the eternal cycle of change within us; the uncanny discovery that the seeker is the mystery which the seeker seeks to know. The hero journey is a symbol that binds, in the original sense of the word, two distinct ideas, the spiritual quest of the ancients with the modern search for identity, always the one, shape-shifting yet marvellously constant story that we find."

This study will be a starting point to others to understand the inner workings of the Hero's Journey and how one determines which part of the story fit into which stage of the Hero's Journey. It also serves as proof whether contemporary works of literature still follow the Hero's Journey storytelling structure and if this is found to be the case, it would therefore lead to a bigger question whether modern day books such as fiction novels and comic books can be considered and categorised as a part of modern mythology.

\section{Research Objectives}

This paper aims at understanding the method how Gaiman incorporates the Hero's Journey and all of its seventeen stages in his novel American Gods. This study also aims to verify if the main protagonist Shadow Moon's journey can be considered a classic hero's journey based on Campbell's monomyth. The research objectives are as follows:

1. Correlate which events of the story fit into the seventeen stages of the Hero's Journey.

2. Provide an explanation and appraisal for the reason why such events would fit into that particular stage of the Hero's Journey. 
INTERNATIONAL JOURNAL OF ACADEMIC RESEARCH IN BUSINESS AND SOCIAL SCIENCES

Vol. 10, No. 3, March, 2020, E-ISSN: 2222-6990 @ 2020 HRMARS

3. Create a platform where others can understand and attempt to apply the Hero's Journey into other modern works of literature, and furthering the literary world's understanding of myth-like storytelling in contemporary works.

\section{Discussion}

In ancient times, myths acted as a spiritual and psychological guidance to mankind, providing symbols that help carry the human spirit onwards. In his book The Hero with a Thousand Faces (1949), Campbell states that:

"We shall have only to follow, therefore, a multitude of heroic figures through the classic stages of the universal adventure in order to see again what has always been revealed...the singleness of the human spirit in its aspirations, powers vicissitudes and wisdom."

This paper investigates how the plot structure in American Gods parallels to that of a myth. At present, the very lack of modern myths is a matter of grave concern, as this might be the cause of our society being highly neurotic. There are a few factors that have caused this drought of modern myths such as the shifting focus of society from spiritual aids to using science as an explanation to everything. This has made our reality comprehensible, but in the process, we have lost all sense of meaning. Love, anger, grief, envy and fear are all parts of the human soul that can be explained by science, but it does not help one's soul to be fulfilled. Myth is not an outdated concept that gradually diminished into society, instead they are stories with a purpose and reason and were written with a higher purpose in mind. Myths are the guidebooks for life itself and the keys to understanding the whole human experience.

The Hero's Journey is just as important today as at any time in the past and that we have a 'story' of OUR time that chronicles OUR hero's journey. The Hero's Journey can function as a distinctive, interactive mechanism that can assist in illuminating our own lives and discover the unconscious challenges that we are encountered with in our everyday lives. As individuals, we are the master of our own spiritual and psychological journey. In order to become a transformed person, we have to relearn, to redevelop ourselves inwardly in order to be harmonious with our preeminent self. We are destined to replicate the cycle of the Journey if we have yet to experience the bliss. This is because our eternal soul longs for this journey of development. That will only be effective if it reflects the journeys of the heroes before us-the myths and the folklore. The only obstacle in our path is us.

Despite its ancient origins, myth can provide much needed orientation and life meaning for the modern individual. This is because Campbell's Monomyth can be applied to help the individual navigate experiences of psychological transformation.

The purpose of this study is to show that American Gods qualifies as a hero's journey and it can provide spiritual and psychological guidance like myths of old. Skillfully interpreted, it can offer crucial direction for the process of deep psychospiritual transformation that Carl Jung called individuation.

\section{Departure}

The Departure is the first section, and it contains 5 stages, during which the hero begins his journey. 
INTERNATIONAL JOURNAL OF ACADEMIC RESEARCH IN BUSINESS AND SOCIAL SCIENCES

Vol. 10, No. 3, March, 2020, E-ISSN: 2222-6990 @ 2020 HRMARS

\section{The Call to Adventure}

"The familiar life horizon has been outgrown; the old concepts, ideals, and emotional patterns no longer fit; the time for the passing of a threshold is at hand." (Campbell, 1949, p. 47)

Campbell states that in the beginning a herald will appear to the hero, literally or symbolically, sending him off on an adventure while distorting the amenity of his existing world. Campbell believes this stage symbolizes a transformation for the hero, whether big or small, embodying the passing from one stage of life to another.

This stage is very much evident when Odin offers Shadow a job to be his personal aid. In the grand scheme of things, this "call" is not by Shadow's own choosing as Odin and Loki had to kill Laura and his best friend who had offered him to work with him. They had to do it, otherwise they knew Shadow would not have gone through with their plans.

\section{Refusal of the Call}

Just like real life, people or in this case the Hero does not always easily heed the call to adventure. He may completely refuse it or even perhaps he is indecisive about it. This in turn ensnares the hero in his own hesitation and inhibits his own personal spiritual growth. When this happens, the hero is in need of outside guidance in order to push him towards the right direction of starting his journey. (Campbell: 1949, p. 54- 63)

Shadow was very much against accepting the job offer at first as he believed that there would still be the job offered by his friend, even if Laura is gone. Shadow also does not accept the job, because (possibly through supernatural powers) of Odin's deceitful nature. But when shadow arrives to his wife's wake, he found out that his friend, who had an affair with Laura, is now dead too, prompting him to accept the job from Odin.

\section{Supernatural Aid}

The hero receives assistance on his journey by a protector that is more than "often a little old crone or old man" (Campbell, 1949, p. 63). This figure usually wields magical or supernatural powers, or is sometimes a judicious guide and "provides the adventurer with amulets against the dragon forces he is about to pass" (Campbell, 1949, p. 63).

Shadow received aid from both the natural and supernatural over the course of the story. Mad Sweeney, gave him a golden coin that represented the power of the sun and was also capable of reviving the dead. Later down his journey, Shadow receives a silver liberty coin (representing the moon) from Zorya Polunochnaya. The silver coin also plays a huge part in the story, as it guided Shadow on the right path while he was in the afterlife. On another occasion, Ganesh, gave Shadow the answer about the mysterious murder that had plagued Lakeside. Bast, Anubis, Thoth and Zorya Polunochnaya, all helped Shadow while he was in the realm of the dead. In return, Shadow who was assisted by the Thunderbirds, reached the battlefield of the gods and personifications, just in time to halt any unnecessary bloodshed.

In regards to his personal metamorphosis, the Land is the ultimate source of guidance. It is the Land that gave Shadow confidence to face the Gods and personification. It also the Land that presented to Shadow about the gods and the world, letting him to decide on his own what the truth is rather than forcing it upon him. Campbell describes the supernatural aid to be a benevolent protector of destiny. The Land perfectly fits this description, as the Land, seem to have the capability of future sight, and 
most possibly is all-knowing in nature. This is showed when the Land tells Shadow about future events, regarding the star people coming to visit the earth people. He predicted that there will be heroes, who will defeat monsters and gift profound knowledge. However, according to the Land, none of them are gods or ever will be (AG, p. 267). The Land is perhaps seen as a laidback "protecting power of destiny" (Campbell, 1949, p. 66), as it merely observes the events of the world unfolding as a consequence of our own doing, rather than sticking to a predetermined blueprint that is definitely going to unfold.

\section{The Crossing of the First Threshold}

An actual or symbolic boundary is traversed through by the hero as enters another reality. This is where the hero's heroic feat will occur. Before making the actual journey itself, typically the hero has to defeat or overcome some kind of guardian. (Campbell, 1949, p. 71-82)

In American Gods, specifically Shadow has to go through 3 thresholds. The first being Shadow leaving prison to a new world, a world without Laura. The world seems familiar but feels so much more harsh and unforgiving, due to Laura's adultery and her untimely death. Another boundary that needs to be traversed is when he decides to work for Odin. Because it is at this point Shadow realises that there is nothing left for him in this world, and is ready to go on an adventure even if he is unaware of his future role in the events that are set to unfold. The final threshold he crosses is when Odin brings him to Valhalla and he leaves his ordinary world, and is finally able to see the gods in their true semblance. This might be the crossing that fits the Campbellian threshold accurately, as Shadow literally travels from the ordinary world to a mythical one.

\section{The Belly of the Whale}

During this stage, it can be said that the hero is "outside" the story. A plethora of factors may have caused this, ranging from the hero outright not choosing to partake on the quest, the hero might have been slain while on his quest, possibly confined or momentarily incapacitated. The hero would seem to be dead as he is succumbed to the void of the unknown due to not being able to overcome or conciliate the power of the threshold.

This stage is seen as the metamorphosis stage the hero must complete in order to reach his Ultimate Boon: "instead of passing outward, beyond the confines of the visible world, the hero goes inward, to be born again" (Campbell, 1949, p. 84). This stage or process indicates the preparedness of the hero to transform into something better.

Shadows true ordinary world is not an actual home or the prison he was jailed in, it is rather the world he knew before his wife's (Laura) untimely demise and the moment Shadow found out she was cheating on him. It can also be combined with the world he knew before the existence of the gods and personifications. When he is on his journey, he does get to have a brief look at his past ordinary world, specifically when he was using the alias Mike Ainsel, during his time at Lakeside. However, he is unable to return due to the fact that he cannot forget what he now knows about the existence of gods and personifications.

There are various moments in the story where Shadow was physically unable to move forward with his journey due to an obstacle of some sort. For example when he was trapped by the personifications subordinates, or even when he was undercover in Lakeside as Mike Ainsel. Perhaps the most fitting 
event in the story that fits this stage is when Shadow passed away. He even decided to live in the void of death rather than return to the journey he was on.

On a spiritual level, Shadow does not escape the belly of the whale till late on in story due to feeling the emptiness in his own soul. We can assume that this started the moment he realised Laura had died and the burden on his soul was even heavier when he found out the love of his life cheated on him with his best friend no less. This was also noticed by the gods particularly Bast and Odin, the former of which is when Shadow realised the all this time he has been "holding his breath... three years... maybe longer" (AG, p. 230). Odin on the other hand who is blessed with an insurmountable amount of knowledge is baffled that Shadow doesn't seem to feel anything ever since Laura's death. He says: "Why don't you argue? ... Why don't you exclaim that it's all impossible? Why the hell do you just do what I say and take it all so fucking calmly?" (AG: 368)

Shadow had to through the "Belly" twice, once physically and once more spiritually. Spiritually, as mentioned before, Shadow needs to feel alive before actually attaining the Ultimate Boon. The physical one however is his death, and the choice he made to stay in the nothingness. Campbell describes this stage a transformation the hero has to go through in order to metamorphose into someone greater. Campbell describes the Belly of the Whale as a path the hero has to "instead of passing outward, beyond the confines of the visible world, the hero goes inward, to be born again" (Campbell, 1968, p. 84). When Shadow was resurrected from the dead, he has truly escape the physical Belly of the Whale and by gaining the ability to live after said resurrection passed through the spiritual Belly of the Whale. It can be argued that this is the most crucial part of the journey for Shadow, and perhaps gaining the ability to live again is his own personal Ultimate Boon.

\section{Initiation}

The middle section is referred to as the Initiation and it has 6 stages. In this section, the hero travels outside his natural world, undergoes and successfully completing trials, and completes his heroic deed as a consequence rewarded with what the hero desired.

\section{The Road of Trials}

A multitude of challenges must be completed by the hero in order to become a bona fide hero. According to Campbell (1949, p. 89), in this stage "the hero is covertly aided by the advice, amulets, and secret agents of the supernatural helper whom he met before his entrance into this region. Or it may be that he here discovers for the first time that there is a benign power everywhere supporting him in his superhuman passage."

The hardest of all stages for any hero, particularly Shadow while he was on his journey. He goes through multiple challenges, that at first seem not connected to one another, but at the end it is made clear, it was all done to prepare Shadow to stop the great war between the gods and personifications.

The thematic trial Shadow had to go through was one of his own loyalty and morality. This was seen when Media, who came to him as Lucy Ricardo, tried to convince Shadow to abandon Odin and come over to the side of the personifications. Shadow quickly turned her down, even disgusted by her bribes. Odin was constantly testing Shadows morality, because he is basically the anti-Shadow. Odin does not care about others and is only looking out for himself, because in his point of view, he was 
INTERNATIONAL JOURNAL OF ACADEMIC RESEARCH IN BUSINESS AND SOCIAL SCIENCES Vol. 10, No. 3, March, 2020, E-ISSN: 2222-6990 @ 2020 HRMARS

brought to this foreign land by people who used to worship him, and now he is left stranded here to slowly die. There are various distinct ways to compare the morality of both Shadow and Wednesday. For example, Wednesday tricks, deceives and even go great strides to get what he wants. Shadow on the other hand, even if he was an ex-convict, tries his best to never harm anyone. Shadow does not really go a change in his morality, as from the get go, starting from page one even, Shadow was always a gentle soul. In a way, Shadow perhaps fail his moral quandary test, when he had to end the murders of Lakeside by killing Hinzelmann, a murderer, but also the man who saved his life.

The series of trials that are more akin to the myths of old, happens when Shadow is traversing through the afterlife. The wisdom gained from the trials is prove to play an important role in Shadow's journey and self-development. For example, Shadow had to choose between the cold harsh truth and beautiful comforting lies. By picking the former of the two, he learnt about his true origin and came to a deeper understanding about himself. This in turn help him gain more leverage against the gods in order to convince them to stop fighting. In his second trial, Shadow is met with Bast in the afterlife where, Bast tells him a path must be made from three which are given. He says: "One way will make you wise. One way will make you whole. And one way will kill you [permanently]." (AG, p. 509). Shadow says he trusts Bast to choose in his stead. Shadow went down the middle path after Bast weighed his heart against a feather. There he had to face his final judgement, and Shadow had to decide what he would want his afterlife to be, in which he responded "...nothing. No heaven, no hell, no anything." (AG, p. 517).

\section{Meeting with the Goddess}

"The mystical marriage with the queen goddess of the world represents the hero's total mastery of life; for the woman is life, the hero its knower and master." (Campbell 1949, p. 111)

During this stage, the hero meets with unequivocal love which is a representation of the hero's link to life, death, and everything that is pure in the world. This particular stage differs for male and female heroes. The male protagonist usually partakes in a "mystical marriage" on equal or even superior grounds, the woman however is in turn conquered by a male god, whether she originally wants it or not. As stated by Campbell, "Then the heavenly husband descends to her and conducts her to his bed- whether she will or no. And if she has shunned him, the scales fall from her eyes; if she has sought him, her desire finds its peace". (Campbell, 1949, p. 109-110)

The Egyptian cat goddess, Bast, befit this stage even if Shadow had met several other goddesses along his journey. Campbell's describes the hero's mystical marriage with the Goddess to be "the hero's mastery over life". Shadow's first encounter with Bast in her human form is in a mixture of dream and reality in which they fornicate with one another. For Shadow, this meeting with this goddess is a profoundly spiritual and cleansing experience that even to a point healed his previous physical injuries. Besides that, what was of more significance is the spiritual healing that Bast conducted upon him: "...he took a breath, a clear draught of air he felt all the way down to the depths of his lungs, and he knew that he had been holding his breath for a long time now. Three years, at least. Perhaps even longer." (AG, p. 230) Shadow was imprisoned because he had attacked and stole from the group of men that he and Laura had conspired to rob a bank. But who tried to steal their share of the money. After doing his time behind bars for 3 years, probably, ever since committing the crime, he haven't been able to vindicate himself of his deed - more so due to the fact that the charges were dropped due to lack of evidence. No matter how much he had thought they had deserved it - even Laura 
haven't been able to pull him out of the guilt - after all, it was her who wheedled him in taking part in the crime. As a complete outsider, Bast, is able to give him a moment of hiatus that does not leave him unaffected. The encounter leaves more than just claw-marks on his skin: his perspective was slightly altered by the experience: "There was an idea that hovered at the edge of his perception. Something about transience. It flickered and was gone" (AG, p. 230)

According to Campbell, this stage epitomize the endless motherly love, as Bast, a mother figure to Shadow. Bast is never controlled or mastered by Shadow - own free will and benign to Shadow with hopes for him to be of use in averting the war between gods and personifications. Furthermore, she saved Shadow from his suicidal thought while he was shaving in front of a bathroom mirror (a reference to The Sandman character Despair) by materializing in cat form distracting Shadow of his suicidal intentions. Occasion that less likely to be coincidental as Shadow was certain the door was locked.

Comparable to Land, Bast is disparate with other gods and myths in a way that she is an outsider in the coming discord - as his final judgement arrived, she told him of her expecting him to take part on averting the conflict as she does not intend to directly involved quoted "like other people picking [her] battles" for her (AG, p. 517). There is an ephemeral quality in Land which also present in Bast she represents the source and continuum of life itself, as well as adapted to and included in nature through her feline side. Shadow's encounter with the deity is both wild and sexual with no shame and guilt involved - Shadow could lower his defences and experience a moment of connection of the world revolving around him through Bast.

\section{Woman as Temptress}

"... everything we think or do is necessarily tainted with the odour of the flesh" (Campbell, 1949, p. 112)

The hero comes to the realization of his own natural cravings of the "flesh", and is followed by repulsion. Campbell states that this temptation is often depicted as a woman but not always necessarily.

In this stage, Shadow does not feel disgusted of his "odour of flesh" - derived from the Meeting with the Goddess, sexuality correlates with spirituality and with life experience. He does encounter a temporal situation of the sort when approached by the Media through his television set and tries to influence him into shift sides in the coming discord. Shadow was asked by the Media, in which appeared as the name character of the TV show I love Lucy, whether he "ever wanted to see Lucy's tits" (AG, p. 188), and appeared irritated rather than excited. It matches Campbell's interpretation of the meaning of this stage, a manifestation of the materialistic blandishment of life. Money, fame and success was offered by Media if he agrees to betray the old gods and sided with the personifications. Shadow denies the temptation. This part can also be interpreted as a challenge the hero (Shadow) must face on his Road of Trials.

\section{Atonement with the Father}

At this stage, the hero has to face whatsoever that holds power over him, usually depicted in many myths by the father figure. After overcoming the "father's ego-shattering initiation" (Campbell, 1949, p. 120), the hero has accomplished what he set out to do and has attained the Ultimate Boon. 
According to Campbell, this stage is basically the reinvention of the hero's own self-image and reach a state of unity and self-understanding.

Atonement with the Father is a stage in which the hero must deal with whatever dominates over him -more often than not it is represented as a father figure. For Shadow - Mr. Wednesday (his father) has manipulated him as a part of his self-centred plan in which only Shadow can stop from ever occurring. Shadow's Atonement, then, is the verdict of their discord when Shadow inhibit Odin's planned extermination of the gods from taking place ergo revoke his resurrection. Shadow's time on the branches of Yggdrasil as well as his conversation with the Land (in his dreams), Bast (at his final judgement), and cultural hero Wisekedjak (in afterlife before his resurrection) have prepared him to recognize the truth about Odin's plans on his own thus allows him to avert it. Odin has already sacrificed himself as part of his own plan in which allows Shadow to face Odin in a non-physical confrontation. It fits Campbell's definition of the meaning of Atonement with the Father: by avoiding Odin's plan from realizing, Shadow practically redefines himself by defeating his own passivity.

Conclusively, at the end of the novel, Shadow undergoes a literal atonement when he goes to Iceland to meet the Icelandic version of his estranged father figure, Odin. Keep in mind that this Odin is not connected to the version that Shadow manage to defeat in America. However, Icelandic Odin's instant acceptance of Shadow is a moment of significance - as is the gratitude and joy of this Odin when Shadow presents him with the fractured glass eye of his American counterpart. Shadow has embraced the idea of Odin as a God of earth's people at least, even if he does not view Wednesday to be shone in the same light as the other version of Odin.

\section{Apotheosis}

Overcoming the previous trails, the hero is transcended to a god-like, enlightened state; possessing knowledge of the gods: "What is understood is that time and eternity are two aspects of the same experience-whole, two planes of the same nondual ineffable" (Campbell, 1949, p. 140).

Apotheosis is a period of enlightenment that follows after the trials and the initiatory phases required in order to attain the Ultimate Boon. Shadow's self-sacrifice on the branches of Yggdrasil is a vital element of his final transition to a wider perception as well as his exposure of the experience of being alive. The Ultimate Boon often requires the hero to reach a moment of enlightenment in order to prepare him for the self-sacrifice.

In Shadow's situation, however, he makes the verdict to achieve the increased level of consciousness only after sacrificing himself. He doesn't seem to be aware of the reason for his decision to hold Odin's vigil on the branches of Yggdrasil. He perform this due to the fact that he does not regard his own life to be on equal footing as the duty he feels he owes to the deceased Odin. Having said all this, after being pulled back from the afterlife, Shadow eventually is prepared for the forthcoming realization that plays an integral role in his Ultimate Boon. Shadow now knows the truth about Odin's plan: "It's a two-man con,' said Shadow. 'It's not a war at all, is it?'” (AG, p. 549) Utilizing this insight, and the details he got from Odin's ghost (whom certain it was too late to stop the war), he is able to assure both the gods and personifications to put an end to their war. 
INTERNATIONAL JOURNAL OF ACADEMIC RESEARCH IN BUSINESS AND SOCIAL SCIENCES

Vol. 10, No. 3, March, 2020, E-ISSN: 2222-6990 @ 2020 HRMARS

\section{The Ultimate Boon}

This is what the protagonist originally set out on an adventure for (usually associated with mystical esoteric powers). The hero might have attained his prize by sheer strength, Machiavellian means, or the hero received it as a reward and this will affect the manner of the return. (Campbell, 1949, p. 159-178)

In a rather unique way in comparison to other myths, Shadow's Ultimate boon is one that is beneficial to the mythical world. To be clear, his will to live and gaining the knowledge of the actual events and truths that he has learnt while on his journey, has allowed Shadow to prevent any form of unnecessary bloodshed to be spilled on the battlefield, be it god or personification. His prevention of his "father"'s plan has also saved mankind from a possibly dark and bleak future as it is noted a few times that Odin despises humans, as he believes that they left him to die on this foreign land. Odin is quoted saying: "'They made me. They forgot me. Now I take a little back from them. Isn't that fair?'" (AG, p. 337). In addition Loki and Odin, both grow stronger in power through war, bloodshed, bedlam and death. It would be safe to assume the world will be in constant conflict if these two were left in charge.

Just like heroes of myth, Shadow does bestow boons to "his people". He removed the gold coin form his wife Laura, due to being in the land of the dead himself, he now understood her mind, body and soul desperately craves the sweet call of death, as she herself feels she does not belong here in this world. In the small town of Lakeside, Shadow gives the kobold, Hinzelmann the gift of life and freedom to live as he always had, as the kobold saved Shadow's life and protects the whole town of Lakeside. This all despite the fact that Hinzelmann had to sacrifice the town's children as a payment for his protection.

\section{Return}

The concluding section referred as Return, has 6 stages. In this phase, the hero returns to his people in the previous natural world with the boon attained.

\section{Refusal of the Return}

Perhaps due to the (not limited to) life changing and inspiring adventure the hero has had in the special world, the hero no longer wants to return to his previous world, and decided to remain in the marvellous realm. (Campbell, 1949, p. 179-182)

Shadow is offered the choice of what kind of afterlife does he want, and he chose not to exist anymore. He feels tired and sick of all that he has been through many trials and tribulations. It is with Eostre's assistance that he has been able to persevere with his quest and fulfil his Ultimate Boon.

\section{The Magic Flight}

If the hero is blessed a supernatural being that previously held the ultimate boon, the hero's return home will be assisted said entity. However if the hero attained the boon through deceiving or in a cunning manner, or there exists god(s) or an evil entity such as demons, will be pursuing the hero, there will be a multitude of dangerous obstacles the hero has to face during this return. (Campbell, 1949, p. 182-192) 
INTERNATIONAL JOURNAL OF ACADEMIC RESEARCH IN BUSINESS AND SOCIAL SCIENCES

Vol. 10, No. 3, March, 2020, E-ISSN: 2222-6990 @ 2020 HRMARS

The Magic Flight stage is not so evident here though a dead hero would have to escape from the netherworld, as so often narrated in hero myths. Assuming there is a method of resurrection, Shadow's return "from the underworld" falls short of his own indisposition.

\section{Rescue from Without}

The hero perhaps requires aid to return to his ordinary world, maybe due to him being weak or the hero has no desire to return. If this is the case, "the world may have to come and get him" (Campbell 1949, p. 192).

Eostre reanimates Shadow and he is brought back from the void that he had opted for as his afterworld. He shows no desire to come back from the dead. In the beginning, Shadow was dismayed by the fact that he was unwillingly resurrected:

'You called me back.' He said it slowly, as if he had forgotten how to speak

English. There was hurt in his voice, and puzzlement. ...'I was done. I was

judged. It was over. You called me back. You dared.' (AG, p. 552)

Upon returning form the land of the dead Shadow slowly but surely becomes a dynamic force and portrays a new character development after being given a new lease of life. Having no regrets in having been brought back to life, Shadow feels that he can endure any future struggles. However, transcending his terror of death, Shadow realizes the sweet call of death was merely a well-deserved rest.

\section{The Crossing of the Return Threshold}

Having return from the mythical world to the hero's home, he now has to figure out how to realise the full potential of his boon (or revelation) and how to teach it to other people in the way they can comprehend it. (Campbell, 1949, p. 201-212)

Shadow is brought back to the Lookout Mountain from the battleground by Mr. Nancy (a.k.a. Anansi). Although he crosses over the Return Threshold, the mythical world cannot be outdistanced. This is because Shadow cannot disregard what he has learned about the mythical quality of the world surrounding him.

\section{Master of Two Worlds}

The hero is able to freely manoeuvre between the natural and mystical "worlds". That is to comprehend his revelation in the natural world and conversely. A balance of sorts is formed between material and spiritual. (Campbell, 1949, p. 212-220)

In American Gods, Shadow is capable of entering the warzone on his own accord, even if the battlefield is located on a plane outside the limits of the ordinary world. This proves that Shadow has mastered his human and demigod sides. However, a closer match is found in Shadow's character development if we consider Campbell's actual explanation of the stage. He has come to terms with the physical life and the metaphysical transience of being human. In Shadow's case, he comprehends that truth is a matter of viewpoints, and an all equitable truth is perhaps inconceivable. In the book, Shadow ponders upon this idea on multiple occasions, one of which was on Lookout Mountain:

A trail of lightning speared across the clouds, and Shadow wondered if that was the thunderbird returning to its high crags, or just an atmospheric discharge, or whether the two ideas were, on some level, the same thing. 
INTERNATIONAL JOURNAL OF ACADEMIC RESEARCH IN BUSINESS AND SOCIAL SCIENCES

Vol. 10, No. 3, March, 2020, E-ISSN: 2222-6990 @ 2020 HRMARS

And of course they were. That was the point, after all. (AG, p. 566)

Freedom to Live

The hero has learned to live without fake or unreasonable self-images, and is able to look forward to the future without fear. "He does not mistake apparent changelessness in time for the permanence of Being, nor is he fearful of the next moment (or of the "other thing"), as destroying the permanent with its change." (Campbell, 1949, p. 225)

Campbell (1968) argues that the major religions cannot serve myths' purpose in modern life, and that without the guidance of myths or any proper replacement, the members of modern societies have to face the stressful transitions of life unprotected and insufficiently prepared. This is also a major cause for increased stress and mental problems. If we accept that various myths and mythologies have served some spiritual function that exceeded entertainment and recreation, and that those myths were written by and for people that lived thousands of years ago, the logical course of action, then, is to find out what that function consists of and whether there is something that can replace it in modern society.

Shadow's hero's journey is not only metaphorical but literal as well. Intitially, Shadow may have had doubts as to the journey not being his own but rather a calling he had to undertake. In reality, the real motive of the journey is to highlight Shadow's development into an absolute human being besides celebrating his procurement at prevailing. Shadow's earlier debilitated apathy is replaced with an awareness of life. "Shadow felt good. ... He couldn't remember the last time he had felt so alive and so together." (AG, p. 549)

\section{Conclusion}

Perhaps the reason the monomyth or the Hero's Journey has remained steadfast after all these years is because it complements the lives of people and the struggles and challenges that they face. It portrays the never-ending battle that mankind has to deal with, as the Hero's Journey is simply a more fantasized version of society's life journey. Everyone at a particular point in time of their lives will undergo different versions of the Hero's Journey. Some of these people will go on to make a difference in their society; but for most, they will become the hero that their family, friends or they themselves need. That is perhaps why it is why Campbell named his book The Hero with a Thousand Faces, as the hero in the Hero's Journey is never only one hero, it is the same idea of what a hero is, but his form, his journey and his goals varies from society to society.

In the case of American Gods, Shadow's hero's journey is not only metaphorical but literal as well. Initially Shadow may have had doubts as to the journey not being his own but rather a calling he had to undertake. In reality, the real motive of the journey is to highlight Shadow's development into an absolute human being, besides celebrating his obtainment to life itself. Shadow's earlier debilitated apathy is replaced with an awareness of life. "Shadow felt good... He couldn't remember the last time he had felt so alive and so together" (AG, p.549).

American Gods therefore follows the Hero's Journey storytelling pattern. Although one of the stages out of the 17 is not clearly evident, which is the Magic Flight, most of the stages are present. Some stages can be interpreted differently by different people but most of them are a clear direct match. It is Campbell's contention that while metaphors of myths change as a culture evolves (Campbell, 2001), the contents of the myths have remained the same. And this content is represented by the 
INTERNATIONAL JOURNAL OF ACADEMIC RESEARCH IN BUSINESS AND SOCIAL SCIENCES Vol. 10, No. 3, March, 2020, E-ISSN: 2222-6990 @ 2020 HRMARS

stages of the Hero's Journey. It can therefore be said that American Gods is capable to be on par with stories from myths of old. Besides, because of the adaptability of the Hero's Journey, almost any work of fiction can be read following this mould.

The major finding of this paper, is that despite the number of years which has past since a millennia ago, mankind still uses the Hero's Journey storytelling structure when writing a story. The fact that it still exists in the twenty-first century and is still appealing to readers is what is quite amazing. This is proven in the fact that American Gods has won multiple awards such as the Nebula Award for Best Novel in 2003, the Hugo Award for Best Novel in 2002, and the list goes on. People are not the slightest least bored of the atypical storytelling structure of the Hero's Journey, and it can be hypothesized that they never will. This paper has carefully elaborated what qualifies for each of the seventeen stages of the Hero's Journey, and as well as shown examples from American Gods that fit into each of the stages. Therefore, readers now have an understanding on how the Hero's Journey storytelling structure can be implemented in modern texts. The mere fact that it uses the same mythlike story telling found in archaic stories such as Beowulf and Odyssey, lends to the argument that modern texts such as American Gods and other texts that implement the Hero's Journey storytelling structure, can be considered as a "modern-myth". However, this is an argument for the future to debate over.

As for recommendations, there are a few which can be suggested. For example, multiple texts from different time periods can be used to show the evolution of the Hero's Journey, or rather, the lack thereof one. By doing so, scholars are able to present the evidence in a chronological sequence which the Hero's Journey had still be implemented by authors throughout time. A second suggestion would be using texts that are from different cultures such as one from the West and one from the East. This would help solidify the fact that the Hero's Journey is not just a Western concept and one which is only utilized by the West, but one which is universal. Scholars can delve into what makes the Hero's Journey so commonly found in texts from various cultures, and why do people who come from worlds apart seem to have the same innate way of telling their stories and myths.

\section{References}

Barry, P. (2017). Beginning theory: An introduction to literary and cultural theory. Manchester: Manchester University Press.

Barton, A. (2018). The Knight's Progress and Virtual Realities: The Medieval Adventure from Beowulf to Ready Player One. Digital Collections. Retrieved from https://digital.library.txstate.edu/handle/10877/7410

Bloom, R. (2013.) Foundations of psychological profiling terrorism, espionage, and deception. Boca Raton, Florida: CRC press.

Campbell, J. (2008). The hero with a thousand faces. Novato, California: New World Library. Ethridge, Kyle, L. (2014.) The queer gothic hero's journey in Oscar Wilde's the picture of Dorian Gray. Hattiesburg, Mississippi: University of Southern Mississippi.

Gad, R. N. (2013). In self-recovery: A mythopoetic analysis of addiction and heroic journeys of the learning disabled. Carpinteria, California: Pacifica Graduate Institute.

Keally, M. (2011). The superman's ancestors - Beowulf, Odysseus and Roy Hobbs: Application and analysis of Joseph Campbell's monomyth theory. University Park, Illinois: Governors State University. 
INTERNATIONAL JOURNAL OF ACADEMIC RESEARCH IN BUSINESS AND SOCIAL SCIENCES

Vol. 10, No. 3, March, 2020, E-ISSN: 2222-6990 @ 2020 HRMARS

Koudelková, L. (2015) Neil Gaiman: Myths in Postmodern Literature [online]. Brno, 2015 [cit. 202004-01]. Available from: <https://theses.cz/id/rj6p6d/>. Master's thesis. Masaryk University, Faculty of Arts. Thesis supervisor M.A. Jeffrey Alan Smith, Ph.D.

Langton, J. V. (2012). Myth in war fiction. Dominguez Hills, California: California State University.

Ninet, A. I. (2009). "Playing at being gods." Philosophia, vol. 38, no. 1, pp. 41-55., DOI: 10.1007/s11406-009-9210-8.

Nusz, L. A. (2004). The foundational structure behind Star Wars. Louisville, Kentucky: University of Louisville.

Propp, V. (1997). Theory and history of folklore. Minneapolis, Minnesota: University of Minnesota Press.

Rode, F. W. (2012). The heroic journey of a common man: benefiting society one journey at a time. Madison, New Jersey: Drew University.

Saussure, F. De. (1959). Course in general linguistics. New York City, NY: Philosophical Library.

Wheeler, A. M. (2017). "The porosity of human/nonhuman beings in Neil Gaiman's American Gods and Anansi Boys." Palgrave studies in animals and literature. New York City, NY: Springer International Publishing. 